\title{
Study the Effect of Corrosion and Scale Inhibitors on Corrosion Rate of Carbon Steel in Cooling Towers Unit in Oil Refineries
}

\author{
Mazin N. Ali ${ }^{1}$
}

\section{Authors affiliations: \\ 1) College of Engineering, Al- Iraqia University, Baghdad- Iraq Mazin2099@yahoo.com Phone: 009647502203070}

\section{Paper History:}

Received: $15^{\text {th }}$ Aug. 2020

Revised: $13^{\text {th }}$ Dec. 2020

Accepted: $23^{\text {rd }}$ Jan. 2021

\begin{abstract}
In the present work the effect of Corrosion \& Scale Inhibitor was evaluated by using of the commercial product (Kurita S2050) that mainly containing of (Na2HPO4) sodium phosphate as corrosion inhibitor and $(\mathrm{C} 6 \mathrm{H} 11 \mathrm{NaO})$ sodium glocunate as scale inhibitor \& dispersant. The dosing rate of this chemical was controlled according to the treatment system depend mainly on the monitoring of LI \& RI indexes for (30) days treatment in the cooling tower unit of Al-Dora Oil refinery-Baghdad. The corrosion rate and the corrosion inhibitors efficiency were calculated by measurement of weight loss in standard test coupon (AISI 1010). After 30 day of the Field Test, the result show that the treatment program performance was effective in the corrosion \& scale inhibition through an acceptable corrosion rate less than 0.018 in gmd. Also the result of corrosion rate was analyzed statistically by using of (ANN) to formulate a prediction equation to corrosion rate identification.
\end{abstract}

Keywords: Corrosion \& Scale Inhibitor, Cooling Tower Unit, Corrosion Rate, ANN.

$$
\begin{gathered}
\text { دراسة تأثير مثبطات التاكل على معدل تاكل الصلب الكربوني في وحدة ابراج } \\
\text { التبريد في مصافي النفط مازن نبيه علي }
\end{gathered}
$$

في هذا البحث تم دراسة تأثير مثبطات التاكل باستخدام المنتج التجاري (Kurita S2050) الذي يحتوي

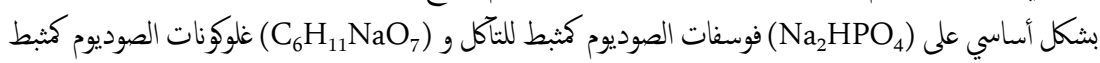

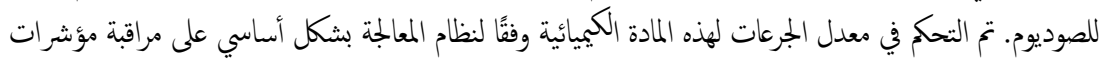

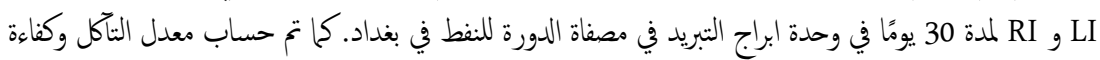

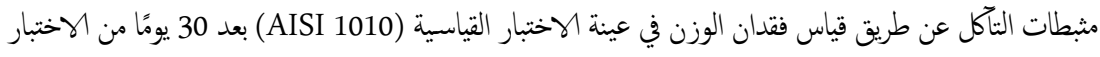

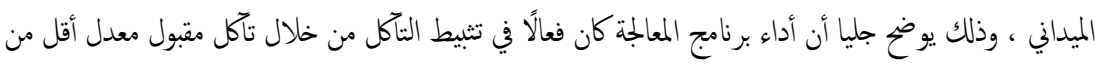

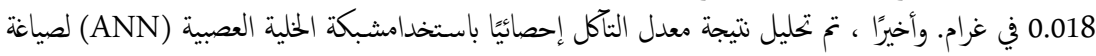

$$
\text { معادلة تنبؤ لتحديد معدلات التاكل. }
$$

\section{Introduction}

The robot Evaporative cooling towers are very popular as they provide the most cost effective cooling technology for commercial air conditioning and industrial processes.

Since the cooling towers deal with water and movement, the problem of corrosion is an important problem to get rid of them, especially as the transfer of water and return to and from the tower is done through a pipe of steel always exposed to problems such as corrosion, erosion and pollution
Corrosion is defined as the electrochemical deterioration of a metal contacts with cooling water. Different elements are required for corrosion to occur such as: (corrodible surface, difference in potential, electron acceptor and electrolyte), Figure (1) give a very clear view of how corrosion occurs.

NJES is an open access Journal with ISSN 2521-9154 and eISSN 2521-9162

This work is licensed under a Creative Commons Attribution-NonCommercial 4.0 International License 


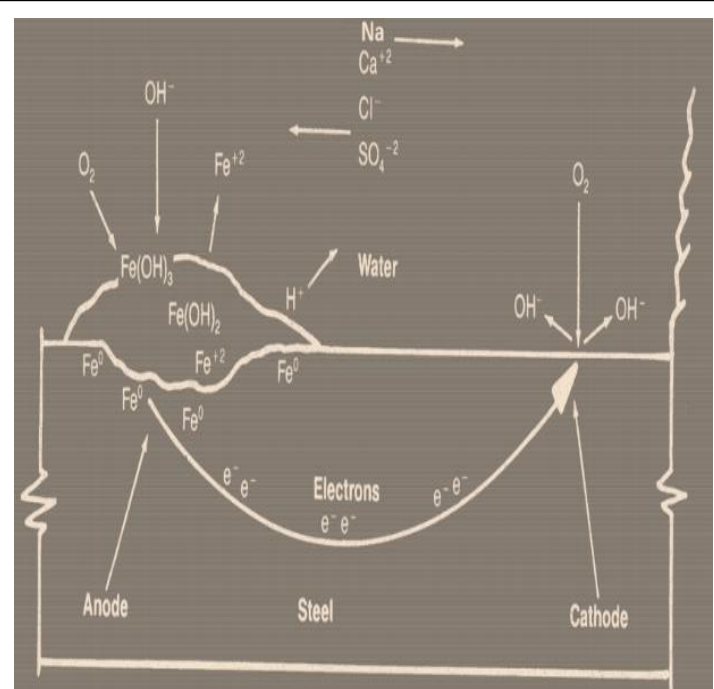

Figure (1): The corrosion cell. [1]

Many refineries aspire to control the chemical treatment system and monitor corrosion rates in cooling towers using corrosion inhibitors, especially with the highest possible percentage of cycle of concentration to reduce water waste and added chemicals. Corrosion inhibitors added as a chemicals to chemical stream to prevent stream to lower the rate of corrosion or prevent corrosion, so that a suitable service lifetime for the processing equipment will done. Corrosion inhibitors are often the most costeffective way to prevent or control corrosion because they allow one to use less expensive metals for a corrosive environment. The criteria for corrosion inhibitors selection was clearly illustrated in Table (1).

Table (1): The criteria for corrosion inhibitors selection [1]

\begin{tabular}{|c|c|c|c|c|}
\hline \multirow{3}{*}{$\begin{array}{l}\text { Corrosion } \\
\text { Inhibitor }\end{array}$} & & \multirow{3}{*}{$\begin{array}{c}\mathrm{PH} \\
\text { Range } \\
\text { (ideal) }\end{array}$} \\
\hline & \multicolumn{3}{|c|}{ Metal } & \\
\hline & Steel & Copper & Aluminum & \\
\hline \multicolumn{5}{|c|}{ Cathodic inhibitor } \\
\hline $\begin{array}{c}\text { Polyphosph } \\
\text { ate }\end{array}$ & Excellent & Attacks & Attacks & 8.5 \\
\hline Zincs salts & Excellent & None & None & $6.5-8.5$ \\
\hline Polysilicate & Excellent & Excellent & Excellent & $7.5-10.0$ \\
\hline Molybdate & Good & Fair & Fair & $7.5-10.0$ \\
\hline \multicolumn{5}{|c|}{ Anodic Inhibitor } \\
\hline $\begin{array}{l}\text { Orthophosp } \\
\text { hate }\end{array}$ & Good & Attacks & Attacks & $6.5-8.5$ \\
\hline Orthosilicate & Good & Good & Good & $7.5-10.0$ \\
\hline
\end{tabular}

Recently, Many researchers was trying to improve the treatment system of corrosion control in cooling tower in order to decrease water loss age in less percentage of chemical conception, Ming-Kai Hsieh1 and etc. have been used a secondary treated that promising alternative to fresh water from municipal wastewater as power plant cooling water system makeup water, where varied chemical treatment evaluated from different corrosion control strategies. Which shows that Orthophosphate was contribute to (more than 80\%) precipitate removal of phosphorousbased corrosion inhibitors and the result shows that free chlorine $1 \mathrm{mg} / \mathrm{L}$ (as $\mathrm{Cl} 2$ ) percentage was approximately $50 \%$ higher than mono chloramine 1 $\mathrm{mg} / \mathrm{L}$ (as Cl2)in mild steel percentage[2]

Adnan S.Nabi and etc. studied the naturally occurring substances (Zizyphus Spina - Chritis ) are increasingly being tried to use in acid cleaning processes corrosion inhibitors of metals to expensive chemicals currently in use and replace some toxic. The minimum corrosion rate by this treatment was 0.20 mpy in concentration of 2.5 after 6 hours. $25 \mathrm{c}$ which leading to an inexpensive and safe environmentally inhibitor formulations indicate have been obtained [3]

Dina R. studied the effect of mixed corrosion inhibitors in cooling system of a using a specimens of (carbon steel), in a mixture inhibitors contains sodium phosphate $\left(\mathrm{Na}_{2} \mathrm{HPO}_{4}\right)$ and sodium glocunate $\left(\mathrm{C}_{6} \mathrm{H}_{11} \mathrm{NaO}_{7}\right)$ the first used as corrosion inhibitor and the last one used as a scale dispersant for (1 to 5 ) days at different temperature $(25,50,75$ and 100$){ }^{\circ} \mathrm{C}$ with different concentrations (20,40,60, and $80 \mathrm{ppm})$. The calculation using un-inhibitors and inhibited water giving $98.1 \%$ to calculate the corrosion inhibitors efficiency. Finally investigations indicate that concentration at $80 \mathrm{ppm}$ and at $100^{\circ} \mathrm{C}$ for 5 days, (i.e, corrosion rate $=0.014 \mathrm{gmd}$ ) decreases the corrosion rate with the increase of the corrosion inhibitors [4]

From the above it was found that the first study cannot be applied in the refinery because it needs additional facilities expensive, but for the researcher Adnan S.Nabi and etc, hydrochloric contradicts with the refinery determinants for the treatment of fat because contamination corrosive and this negatively affects the production process. The results are laboratory-based but have not been tested on a large scale as a field trial.

This work aims to use the commercial chemicals corrosion and scale inhibitors to gain a minimum chemical conception with the higher cycle if concentration. Also this work combine the previous researches with a novel method by ANN to create a mathematical relationship between the inhibitors and the corrosion rate at maximum cycle of concentration.

\section{Strategy of the proposed work:}

It can be divided the strategy of present work into: 1 Experimental work.

2 Analytics work by Artificial Neural network (ANN). Where the experimental work can be sub divided into:

\section{First stage (chemical composition):}

Using (AISI 1010 carbon steel) specimens, chemical composition and physical properties was illustrated in the table (2).

Table (2): Chemical composition and physical properties of AISI 1010[4]

\begin{tabular}{|c|c|c|}
\hline \multicolumn{3}{|c|}{ Chemical Properties } \\
\hline Element & Content & \\
\hline $\mathrm{Fe}$ & $99.18-99.62 \%$ & \\
\hline $\mathrm{Mn}$ & $0.30-0.60 \%$ & \\
\hline $\mathrm{S}$ & $<0.050 \%$ & \\
\hline $\mathrm{P}$ & $<0.040 \%$ & \\
\hline $\mathrm{C}$ & $0.080-0.13 \%$ & \\
\hline \multicolumn{3}{|c|}{ Physical Properties } \\
\hline Properties & Metric & Imperial \\
\hline Density & $7.87 \mathrm{~g} / \mathrm{cm} 3$ & $\begin{array}{c}0.284 \mathrm{Ib} / \\
\text { in } 3\end{array}$ \\
\hline
\end{tabular}




\section{Second stage (Field Test):}

The blow down was done at 50 cubic meters per hour for 54 hours for the purpose of unloading the previous chemicals. Addition of chemicals (biocide, bio dispersant) and the amount of $25 \mathrm{~kg}$ of each of the articles. A sample of the tower water was taken to examine the bacteria (aerobic \& anaerobic \& SRB). Both orthophosphate \& total phosphate were examined before adding the substances in the control lab in the oil refinery (hack 2700) and the result was shown in table (3).

Table (3): The orthophosphate \& total phosphate result

\begin{tabular}{|l|l|l|}
\hline No & Element & Result \\
\hline $1-$ & Orthophosphate & $2.4 \mathrm{mg} / \mathrm{PO}_{4} \mathrm{O}^{-3}$ \\
\hline $2-$ & Total phosphate & $1.8 \mathrm{mg} / 1 \mathrm{Po}_{4} \mathrm{O}^{-3}$ \\
\hline
\end{tabular}

Blow down had been closed and biocide and bio dispersant were added directly to the basin as a preliminary payment to clean the basin. For 24 hours from the date of addition Passivation for prevention. Falling Turbidity to FTU $=16$ and then closing the Blow down and adding the 200-liter Corrosion inhibitor directly to the sink as a shock impulse at 10 o'clock am. After the addition of the corrosion inhibitor, the laboratory tests for the elements were performed in table (4) as shown.

Table (4): The result of elements after adding the corrosion inhibitors

\begin{tabular}{|c|c|c|}
\hline No & Element & Result \\
\hline 1 & Total phosphate & $5.03 \mathrm{mg} / \mathrm{L} \mathrm{Po}_{4} \mathrm{O}^{-3}$ \\
\hline 2 & Ortho & $1.79 \mathrm{mg} / \mathrm{L} \mathrm{PO}_{4} \mathrm{O}^{-3}$ \\
\hline 3 & Sulfate & $290 \mathrm{mg} / \mathrm{L} \mathrm{So}_{4} \mathrm{O}^{-2}$ \\
\hline 4 & M- alkanity & $196 \mathrm{mg} / \mathrm{L}$ as CaCO \\
\hline 5 & Chloride & $260 \mathrm{mg} / \mathrm{L} \mathrm{CL}^{-1}$ \\
\hline 6 & Iron & $0.25 \mathrm{mg} / \mathrm{L} \mathrm{Fe}$ \\
\hline 7 & Total hardness & $328 \mathrm{mg} / \mathrm{L}$ as $\mathrm{CaCO}_{3}$ \\
\hline
\end{tabular}

The results were acceptable as a preliminary start of the experiment and thus began to work Dosage by a small amount of $32 \mathrm{ml}$ per minute with one pump Every dosage test coupon specimens had been cleaned and the rate of corrosion by weight loss age had been measured.

\section{Third stage (Results of experimental work):}

Table (5) shows the concentration of chemicals with time of treatment on the corrosion rate.

Table (5): shows the concentration of chemicals with time of treatment on the corrosion rate

\begin{tabular}{|c|c|c|c|c|c|c|}
\hline $\begin{array}{c}\text { Tim } \\
\text { e/ } \\
\text { day }\end{array}$ & $\begin{array}{c}\text { Conc } \\
\text { In } \\
\text { PPM }\end{array}$ & $\begin{array}{c}\text { Weight } \\
/ \text { Wl in } \\
\text { gram }\end{array}$ & $\begin{array}{c}\text { Weight } \\
\text { / Wl in } \\
\text { gram }\end{array}$ & $\Delta \mathrm{W}$ & $\begin{array}{c}\text { Surface } \\
\text { area } \\
(\mathrm{cm}) 2\end{array}$ & $\begin{array}{c}\text { C.R. } \\
\text { in } \\
\text { gmd }\end{array}$ \\
\hline 1 & 20 & 47.1500 & 47.1516 & 0.0016 & 0.00625 & 0.24 \\
\hline 2 & 40 & 47.1500 & 47.1514 & 0.0014 & 0.00625 & 0.21 \\
\hline 4 & 60 & 47.1400 & 47.1412 & 0.0012 & 0.00625 & 0.18 \\
\hline 6 & 80 & 47.1400 & 47.1411 & 0.0011 & 0.00625 & 0.16 \\
\hline 8 & 20 & 47.1400 & 47.152 & 0.002 & 0.00625 & 0.15 \\
\hline 10 & 40 & 47.1500 & 47.1519 & 0.0019 & 0.00625 & 0.14 \\
\hline 12 & 60 & 47.2999 & 47.301 & 0.0011 & 0.00415 & 0.13 \\
\hline 14 & 80 & 47.2999 & 47.3008 & 0.0009 & 0.00415 & 0.10 \\
\hline
\end{tabular}

\begin{tabular}{|l|l|l|l|l|l|l|}
\hline 16 & 20 & 47.1500 & 47.1519 & 0.0019 & 0.00625 & 0.097 \\
\hline 18 & 40 & 47.1400 & 47.1418 & 0.0018 & 0.00625 & 0.092 \\
\hline 20 & 60 & 47.1400 & 47.1411 & 0.0011 & 0.00415 & 0.088 \\
\hline 22 & 80 & 47.2999 & 47.3007 & 0.0008 & 0.00415 & 0.064 \\
\hline 24 & 20 & 47.1423 & 47.1439 & 0.0016 & 0.00625 & 0.049 \\
\hline 26 & 40 & 47.1400 & 47.1411 & 0.0011 & 0.00625 & 0.033 \\
\hline 28 & 60 & 47.3300 & 47.3305 & 0.0005 & 0.00415 & 0.024 \\
\hline 30 & 80 & 47.3300 & 47.3303 & 0.0003 & 0.00415 & 0.018 \\
\hline
\end{tabular}

While, figure (3) shows that the effect of concentration during 30 days on the corrosion rate

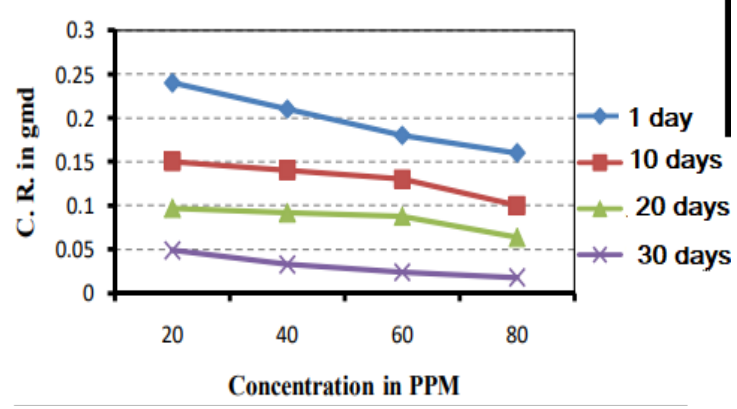

Figure (3): The effect of concentration during 30 days on the corrosion rate.

The table and figure shows that the rate of corrosion was inversely proportional with the chemical dosage and days of treatment this was because the film formation of iron phosphate $\left(\mathrm{Fe}_{2}\left(\mathrm{PO}_{4}\right)_{2}\right)$ produced to protect the surface of the specimen to passivity them and prevent the corrosion .as shown in the equation: $2 \mathrm{Na}_{2} \mathrm{HPO}_{4}+3 \mathrm{Fe}+2 \mathrm{H}_{2} \mathrm{O} \rightarrow \mathrm{Fe}_{3}\left(\mathrm{PO}_{4}\right)_{2}+4 \mathrm{NaOH}+$ $\mathrm{H}_{2} \ldots$ (5)

Also, this results indicate that when the specimen replaced every 10 days at different chemical dosage concentration within $20-80$ ppm for 30 .

\subsection{Analytic work by ANN:}

In this stage a program had been created using MATLAB, so as to study the effect of Corrosion \& Scale Inhibitor (KURITA S-2050) on corrosion rate by a relation between input data and output data. A program had been created using MATLAB to apply ANN technique and detect the mathematical description shown in figure (4), (5), (6), (7). Fitting data to get the equation of output that indicates the best target from figure (4) to figure (7), the equation (output $=1 *$ target +0.0083 ) gives the best mathematical relation between the input and output equation as shown in figure (7).

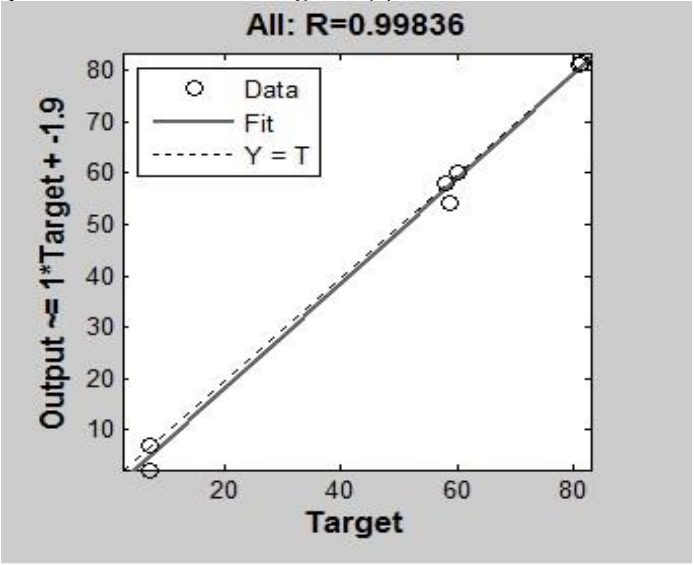

Figure (4): shows relation between KURITA S-2050 and corrosion rate in 5 days 
Also, these results indicate that when the specimen

All: $\mathbf{R}=0.99787$

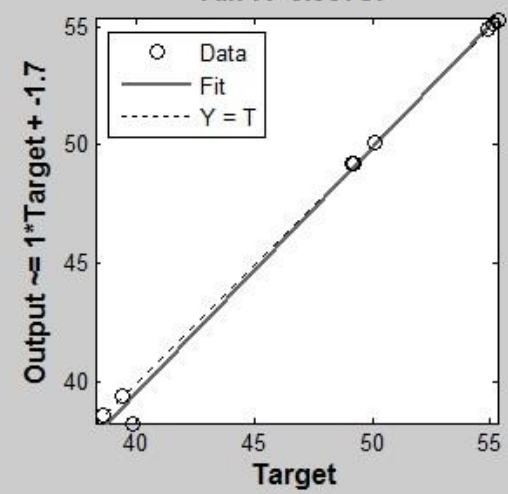

Figure (5): shows relation between KURITA S-2050 and corrosion rate in 10 days

All: $\mathbf{R}=0.99654$

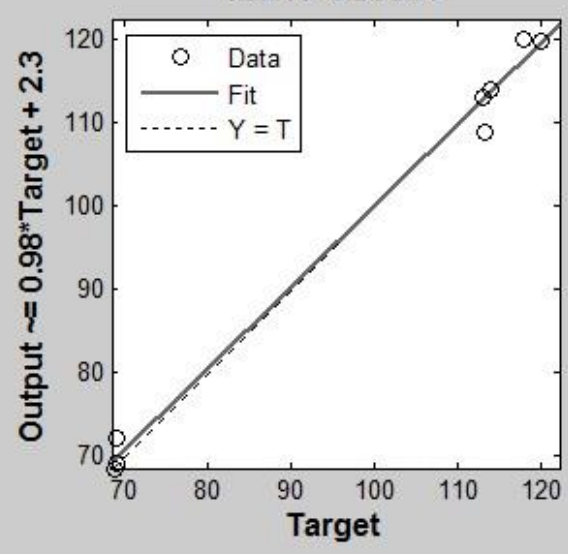

Figure (6): shows relation between KURITA S-2050 and corrosion rate in 20 days

All: $\mathbf{R}=\mathbf{0 . 9 8 5 8 3}$

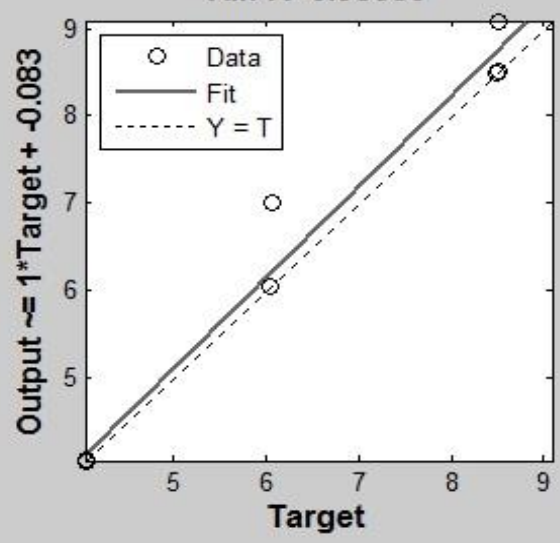

Figure (7): shows relation between KURITA S-2050 and corrosion rate in 30 days

\section{Conclusions:}

From the present work it can be conclude the table (5) and figure (3) shows that the rate of corrosion was inversely proportional with the chemical dosage and days of treatment this was because the film formation of iron phosphate $\left(\mathrm{Fe} 2\left(\mathrm{PO}_{4}\right)_{2}\right)$ produced to protect the surface of the specimen to passivity them and prevent the corrosion as shown in the equation:

$$
\begin{aligned}
2 \mathrm{Na}_{2} \mathrm{HPO}_{4}+3 \mathrm{Fe} & +2 \mathrm{H}_{2} \mathrm{O} \rightarrow \mathrm{Fe}_{3}\left(\mathrm{PO}_{4}\right)_{2}+4 \mathrm{NaOH} \\
& +\mathrm{H}_{2} \ldots(5)
\end{aligned}
$$

replaced every 10 days at different chemical dosage concentration within $20-80 \mathrm{ppm}$ for 30 . Also it can be predict the mathematical formula between input and output to estimate the rate of corrosion for the metal treated with Corrosion \& Scale Inhibitor using the commercial product (Kurita S2050) in cycle of concentration (9) instead of (3) which decrease the loose of water and decrease the rate of corrosion, and the result of (ANN) gave good agreement compare with experimental data.

\section{References:}

[1] 1- Perry R.H. and C.H. Chilton, Chem Eng. Hand-Book, 6 th Ed., Mc Graw Hill, 1998.

[2] 2- Ming-Kai Hsieh, Heng Li, Shih-Hsiang Chien, Jason D. Monnell, Indranil Chowdhury, David A. Dzombak and Radisav D. Vidic, Corrosion Control When Using Secondary Treated Municipal Wastewater as Alternative Makeup Water for Cooling Tower Systems, Water Environment Research, Volume 82, No.12, pp2-4, 2010.

[3] 3-Adnan S.Abdul Nabi and Hanan M.Ali, Corrosion Inhibition of Carbon steel on Hydrochloric acid Using Zizyphus Spina Chritisi Extract, Ournal Basrah Researches (Sciences), Vol. 35, No. 1,pp12-14. 2009

[4] 4-Dina Raheem, Effect of Mixed Corrosion Inhibitors in Cooling Water System, Water Environment Research, Volume 82, Number 12 Al-Khwarizmi Engineering Journal, Vol. 7, No. 4, pp76- 87, 2011.

[5] 5-G. S. Vasyliev, The influence of flow rate on corrosion of mild steel in hot tap water, Corrosions Sciences research .,Vol. 98, No.2, pp33-39, 2015.

[6] 6-N.O. Eddy, in: S.K. Sharma (Ed.), Green corrosion chemistry and engineering: opportunities and challenges, John Wiley \& Sons, 2011.

[7] 7-S. Takasaki, Development of Environmentally Acceptable Technology for Cooling Water Treatment, Zairyo-to-Kankyo, Vol. 64, No.2, pp114-120, 2015

[8] 8-K. Otani, M. Sakairia, R. Sasaki, A. Kaneko, Y. Seki, Effect of metal cations on corrosion behavior and surface film structure of the A3003 aluminum alloy in model tap waters, J. Solid State Electrochem.,Vol.18, pp325-332, 2014.

[9] 9-Ulig, H.H., Corrosion and Corrosion Control, 3 rd Edition. Wiley-Interscience Publicatio, Newyork, 1985.

[10] 10- Perry R.H. and C.H. Chilton, Chem Eng. Hand-Book, 6 th Ed., Mc Graw Hill, 1998. 